\title{
Braille Material Production for Special Education Teachers
}

\author{
Thiago Ribeiro Duarte1,2, Lisânia Cardoso Tederixe1,2, Tânia Maria Moratelli Pinho',2, \\ Cristina Maria Carvalho Delou ${ }^{2,3}$, Edicléa Mascarenhas Fernandes ${ }^{2,4}$, Neuza Rejane Wille Lima ${ }^{2 *}$
}

${ }^{1}$ Benjamin Constant Institute (IBC), Rio de Janeiro, Brazil

${ }^{2}$ Professional Master's Course in Diversity and Inclusion, Fluminense Federal University (UFF), Niterói, Brazil

${ }^{3}$ Post-Graduation Program in Science and Biotechnology (PPBI), Fluminense Federal University (UFF), Niterói, Brazil

${ }^{4}$ Special Inclusive Education Center, Rio de Janeiro Stadual University, Rio de Janeiro (UERJ), Brazil

Email: ^rejane_lima@id.uff.br

How to cite this paper: Duarte, T. R., Tederixe, L. C., Pinho, T. M. M., Delou, C. M. C., Fernandes, E. M., \& Lima, N. R. W. (2020). Braille Material Production for Special Education Teachers. Creative Education, 11, 652-673.

https://doi.org/10.4236/ce.2020.115049

Received: March 18, 2020

Accepted: May 9, 2020

Published: May 12, 2020

Copyright (C) 2020 by author(s) and Scientific Research Publishing Inc. This work is licensed under the Creative Commons Attribution International License (CC BY 4.0).

http://creativecommons.org/licenses/by/4.0/

\begin{abstract}
The lack of didactic materials printed in Braille impairs the learning of the visually impaired students regarding obtaining knowledge through reading. This panorama stems mainly from the ineffective use of the resources offered for Braille printing, more specifically, in relation to the inappropriate use of existing printers. The purpose of the present study was to report the effectiveness of three workshops offered to train professionals in the field of Special Education in the use of Braille Basic-D v4 and Enabling Juliet pro 60 printers. After each workshop, a questionnaire was applied to the participants to evaluate teacher didactics; accessibility to printers; the capacity for autonomous production of materials; and the time available to carry out the activities. The obtained responses about the teacher's didactics and the content of the workshops were approved by the participants. The methodology developed by the present study served to elaborate a workshop that has been offered regularly at Instituto Benjamin Constant. This workshop contributes to reduce the critical process of Braille disuse (debrailization) that involves the education process of visually impaired students.
\end{abstract}

\section{Keywords}

Assistive Technology, Debrailization, Tactile Reading, Visual Impairment

\section{Introduction}

We can see that the world is shown through shapes and colors. The same happens with pedagogical materials in which there is a predominance of scenes and visual activities, which, if not well adapted for the visually impaired, especially 
the blind, lose their meaning, even that is by audio description. The quotes below served as a support for deepening the described problem.

The predominance of eminently visual teaching resources causes a fragmented view of reality and diverts the focus of interest and motivation from blind and low vision students. The resources destined to the Specialized Educational Assistance of these students must be inserted in everyday situations and experiences that encourage the exploration and the full development of the other senses. The variety, adequacy and quality of the available resources allow access to knowledge, communication and meaningful learning.

The making of teaching resources for blind students must be based on some very important criteria for the efficiency of their use. Among them, we highlight the fidelity of the representation, which must be as accurate as possible in relation to the original model. In addition, it must be attractive to the eye and pleasant to the touch.

The blind student needs adapted materials that are adequate to the synesthetic, auditory, olfactory tactile knowledge-especially tactile graphic materials and Braille. Adaptations of materials aim to guarantee access to the same information that other children have so that the blind child is not at a disadvantage compared to his peers (Nunes \& Bitencourt, 2010: p. 60).

\subsection{Braille System}

The Braille system is a process of writing and reading based on 64 symbols in relief, resulting from the combination of up to six points arranged in two columns of three points each. You can represent both letters, numbers and punctuation marks. It is used by people who are blind or have low vision, and reading is done from left to right, with the touch of one or two hands at the same time (Loomis, 1942; National Braille Week, 2020).

The code was created by the Frenchman Louis Braille (1809-1852), who lost his vision at 3 years old and created the system at 16 . He had his eye pierced by a tool in his father's workshop, who worked with leather. After the incident, the boy had a serious infection, resulting in blindness in both eyes (Loomis, 1942; Noah, 2013; National Braille Week, 2020).

Brazil has known the system since 1854, the date of the inauguration of the Benjamin Constant Institute (IBC), in Rio de Janeiro, called, at the time, the Imperial Institute for the Blind Children. Founded by D. Pedro II, IBC already had the mission of educating and professionalizing people with visual impairments. Brazil was the first country in Latin America to adopt the system, brought by José Álvares de Azevedo, a young blind man who had contact with Braille in Paris (Associação de Pais e Amigos dos Deficientes Visuais, 2020).

The Braille code was not the first initiative that allowed blind people to read. There were methods with embossed inscriptions, usually done by letters sewn on paper, which were very large and impractical (Loomis, 1942).

Four years before creating his method, Louis Braille had contact with a captain of the French artillery who had developed a system of night writing, to faci- 
litate secret communication between soldiers, already using points in relief. Braille simplified this work and improved it, allowing the system to also be used for numbers and musical symbols (Loomis, 1942; Associação de Pais e Amigos dos Deficientes Visuais, 2020).

The lack of information is still the main problem. Many teachers think it is simple to teach Braille to a blind student. However, literacy with this system has its specificities, and the teacher, to perform this task successfully, must seek help, explains the expert (Duarte, 2017; Duarte \& Lima, 2017; Associação de Pais e Amigos dos Deficientes Visuais, 2020).

\subsection{Debrailization Phenomenon}

At the end of the 20th century and the beginning of the 21st century, computer resources became instruments to support education in general. In an increasingly computerized world, the speed with which news and topics appear to society, as well as the globalization of access to information, among other factors, encourage the search for other educational practices that aim to immerse students in new sources access to knowledge that can lead to "debrailization" if the Braille System and information technology do not go together (Belarmino, 2001); Primarily, the format chosen was a four-hour workshop, offered at Benjamin Constant Institute (IBC) in partnership with UFF.

As a teacher, observing aspects in addition to those included in the questionnaires, always seeking to complement the practice and ensure a theoretical and methodological evolution of the focus of the workshop. The professor based himself on the actions proposed by Tripp (2005: p. 8): "in action research, we tend to engage in inductive theorizing only when there is no pre-existing explanation or theory that satisfactorily explains whatever we have observed or are trying to observe, so that action research researchers often operate deductively, especially in the initial stages" (Borges \& Chagas Jr., 2001; Borges, 2009; Vilaronga \& Caiado, 2013; Souza et al., 2016; Batista, 2017; Batista et al., 2017; Duarte, 2017; Batista et al., 2018).

In the progress of learning, there is a need for support and technical help for the successful education of students with visual disabilities, in the development of their skills, in access to school syllabus, in visiting museums, among others (Brazil, 1996; Brazil, 2007; Bigate et al., 2017; Bigate \& Lima, 2019).

According to Batista (2018: p. 8):

Debrailization, that is, the underutilization of the Braille system in the education of blind students prevents the creation of conditions for the literacy of blind students and limits the development of psychic functions since writing involves abstraction and complex processes.

Different playful strategies and audio descriptions can also make it possible to teach content that is difficult to understand for people with visual impairments, as they require abstraction and interpretation of images - as are the cases of $\mathrm{Bi}$ - 
ology, Geometry and Geography (Lima \& Fonseca, 2014; Lima, 2015; Pinho et al., 2016a, 2016b; Pinho \& Lima; 2017a, 2017b; Perdigão \& Lima, 2017).

However, the use of textbooks adapted to the Braille System (Lemos \& Cerqueira, 1996; Duarte \& Lima, 2017; Duarte, 2017; Souza, 2018) should not be forsaken. In the domain of the acquisition of mathematical structures, Moraes (2016) also analyzed the importance of manipulating didactic materials in Braille for the acquisition of concepts and the danger of the debrailization of teaching in the educational process of blind students.

Souza (2018) uses the concept of tactile multivalency and argues that Braille writing is important in the sense of enabling a dialogue between hand and brain, as it involves synapses and fundamental connections for the consolidation of the child in the cultural process.

However, on World Braille Day, January 4, the Dorina Nowill Foundation for the Blind ("Fundação Dorina Nowill para Cegos"-FDN, in Portuguese, https://www.fundacaodorina.org.br) located in São Paulo, Brazil highlighted on its website (https://www.fundacaodorina.org.br) that we are still faced, after almost 200 years of creation of this writing methodology, with the need to disseminate and teach this method of literacy to visually impaired students and their teachers.

According to Tederixe (2019: p. 6), "the reading and writing method is done by literacy in the Braille System, so that this method is effective, the blind child must be well prepared in advance in some aspects: motor coordination, sensory, cognitive, psychological and socio-affective stimuli."

Currently, there are many types and models of Braille printers such as Basic-D v4 and Enabling Juliet pro 60-which have a very high production capacity, both in the quantity of impressions generated and in the quality of Braille (Duarte \& Lima, 2017; Duarte, 2017).

At the beginning of the 1990s, the production of printed material in Braille started to be carried out in a fully computerized way as a result of two computer printers, from a German company, purchased by the Benjamin Constant Institute, with resources from the National Education Development Fund (https://www.fnde.gov.br) (Duarte, 2017).

Subsequently, other schools and institutions also began to import this equipment in order to meet the growing demand for material, thus adapting to the new educational inclusion policies. However, some problems happened, preventing a significant advance of this production: lack of adequate maintenance; no Braille coding in Portuguese; lack of interest of major software developers in adapting their programs to our language, increasing the cost of foreign software licenses (Duarte, 2017).

Despite the importance of literacy in Braille, all currently existing technological resources combined with the culture of quick and easily accessible information have generated the discontinuity of tactile reading and fostered the assimilation of audio resources (Duarte \& Lima, 2017; Duarte, 2017). 
An analysis carried out by Batista et al. (2017: p. 1), of what was published in the last ten years pointed out that:

... there is a silencing of the use of Braille and the role of the school and the teacher in these processes, a situation that deserves further analysis and deepening, as the role of the school, the educator and Braille itself is central to being able to seek the quality of teaching for the blind student, especially with regard to literacy. (Batista et al., 2017: p. 1).

The easiest way to obtain audio resources (screen readers, cell phones, MP3 players and audio books); the high costs of producing materials printed in Braille; and the specificity of the professionals working in the transcription, are making the use of tactile reading in a secondary place in all educational spheres or, worryingly, be discontinued, as explained by Souza (2001: p. 1):

And here I am talking about "debrailization", which is nothing but talking about a kind of "death" of Braille, also bringing to our community, a reflection on how we have used Braille, about what we have done for this invention that has not yet completed two hundred years is explored in all its complexity and importance (Souza, 2001: p. 1).

As much as the student not qualified to read has an initial contact with the Braille System, there must be a continued use of this official reading system without migrating to the use of audiobooks only. If so, the education of this student will be seriously compromised, since the learning of the Braille System is fundamental for the cognitive development and the insertion of the individual in the activities of reading, writing and comprehension of texts.

Souza (2001: p. 1) emphasizes this theory stating that:

In the future, we may have children and teenagers who are extremely adept at using the computer, who, however, deprived of reading and writing Braille, will become "illiterate in Braille", thus crippled with direct information about spelling, grammar, interpretation and so many other tools that only direct reading and writing can ensure (Souza, 2001: p. 1).

However, with each new National Book and Teaching Material Program (PNLD_ "Programa Nacional do Livro e do Material Didático", in Portuguese), there are fewer books in Braille and more materials adapted for audio. This phenomenon of debrailization, in Brazil and in the world, could produce a generation of visually impaired people who are not qualified to read and write, thus returning to the condition that existed in the middle of the 19th century when the culture of the blind was basically oralized (Franco \& Dias, 2007).

As emphasized in Batista et al. (2017: p. 181): "it is important to highlight that writing and reading are older devices and used to communicate, both for the seer and the blind, but for this Braille is the tool that allows access to communication through written language". Thus, all actions and practices aimed at pro- 
ducing materials necessary for teaching writing and reading in Braille must be guided by effective strategies, as obtained through the tested and developed workshops.

\subsection{Public Policy and Resources Multifunction Rooms}

The inclusion paradigm lay down as a public policy centered on people with disabilities and their access to education and citizenship, established, at school level, the need to review various aspects of the school, among them, the role of special education teachers. The purpose of this action is to provide students with disabilities, included in regular classes, with support in promoting access to the curriculum.

The curricular adaptation is foreseen in the Brazilian's Law of Guidelines and Bases of National Education, in its article 26:

Art. 26. Primary and secondary education curricula must have a common national base, to be complemented, in each education system and school establishment, by a diversified part, required by the regional and local characteristics of society, culture, economy and the clientele (Brazil, 1996).

Despite the creation of the "Program for the Implementation of Multifunctional Resource Rooms" by Normative Ordinance n ${ }^{\circ} 13$, of April 24, 2007, it is a pioneering initiative for the development of inclusive space in regular schools, with technological resources to support students with special educational needs, computerized Braille printing was carried out in some institutions, schools and foundations specialized in assisting visually impaired students.

This scenario disfavors the debilitation desired by educators and visually impaired people (Souza, 2001; Vilaronga \& Caiado, 2013; Duarte, 2017). The assembly of the Multifunctional Resource Rooms (MRR is the responsibility of both the federal government and the public schools contemplated. This structuring generated a movement to encourage the training of professionals in the area of Special Education and people who serve students with visual impairments who seek greater knowledge on the subject (Orrico et al., 2009). Regarding this training, we can highlight that one of the reasons for the implementation of the MRR was to decentralize the production of printed materials in Braille, until then carried out in large producing centers such as the Benjamin Constant Institute (http://www.ibc.gov.br/) and the Foundation Dorina Nowill for the Blind, which would require an improvement of the professionals who would be in charge of this task.

The Brazilian Ministry of Education has, in recent years, pursued a policy of decentralizing the production of books in Braille, through the Pedagogical Support Center for Assistance to Visually Impaired ("Centro Pedagógico de Apoio à Assistência a Deficientes Visuais"-CAP, in Portuguese) that are installed in almost all units of the Brazilian Federation. These structures can assume an important part of this task, but in order for them to effectively contribute, their 
technicians need to acquire adequate training; if this issue has not been neglected, there is still a need to implement a supervision and technical support structure that can accompany most CAP in carrying out this work (Silva, 2001).

\subsection{Professional Training Need}

Even after the supply of a large number of Braille printers by Ministry of Education (Ministério da Educação-MEC, in Portuguese), through the assembly of resource rooms, the lack of people duly qualified to operate them resulted in a great disuse, causing degradation, underutilization and, in some cases, scrapping (Duarte, 2017).

The result of this abdication of the use of the Braille System at the expense of technological resources ends up generating immense difficulties in the correct use of the Portuguese language and Braille writing (Duarte, 2017).

As Almeida (2014: p. 15) emphasized:

The period of literacy/literacy is the period in which the most serious problems that arise during the mental development of the blind or low vision child arise. In this phase, interpretative schemes of fundamental importance are activated. If there have been failures in the construction of cognitive structures during the evolutionary stages of this development, the literacy process will be delayed, it will become impoverished, mechanical and will bring to the literacy enormous difficulties and profound failures (Almeida, 2014: p. 15).

Thus, it was justified to concentrate efforts on the concept of initial training of these professionals, so that they can work using the Braille printers, with consistent knowledge about the basic configurations and a strong approach in handling them, in order to avoid future wear problems and maintenance, extending the durability and avoiding expenses on repairs of this equipment. According to Orrico et al. (2009: p. 121), "the schooling and education of the blind or visually impaired person is, in general, feasible at all levels, as long as the necessary means are provided for the development of their autonomy and independence".

This whole socio-political-pedagogical scenario in Brazil, about to the education of people with visual impairments, more specifically, blindness, resulted in the main objective of this research, which was to analyze and report the results obtained through the application and evaluation of questionnaires that tested the effectiveness of three workshops offered to standardize the creation of a course in order to train professionals in the field of Education, Special Education.

\section{Material and Methods}

The project was registered on the SIGPROJ platform (Protocol number 216867.938.51214.10112015) as an extension activity at the Inclusion School of the Fluminense Federal University (UFF), Niterói, Brazil, which has authorization 
to operate by the Ethics Committee.

This study is the product of a dissertation of a professional master's dissertation in Diversity and Inclusion (Curso de Mestrado Profissional em Diversidade e Inclusão-CMPDI, in Portuguese; Duarte, 2017).

First, the teachers in the multifunctional resource rooms were prioritized as the target audience for the research. All workshop participants signed an Informed Consent Form. An action research focused on both self-assessment and qualitative assessment was carried out continuously by the participants themselves.

The data were obtained through the application of questionnaires to the professionals who participated in the workshops after the activities proposed to evaluate six items (Table 1).

Primarily, the format chosen was a four-hour workshop, offered at Benjamin Constant Institute (IBC) in partnership with UFF.

As a teacher, observing aspects in addition to those included in the questionnaires, always seeking to complement the practice and ensure a theoretical and methodological evolution of the focus of the workshop. The professor based himself on the actions proposed by Tripp (2005: p. 8): "in action research, we tend to engage in inductive theorizing only when there is no pre-existing explanation or theory that satisfactorily explains whatever we have observed or are trying to observe, so that action research researchers often operate deductively, especially in the initial stages".

Based on these data, reformulations, modifications and rectifications were implemented in the two subsequent workshops, aiming at improving the practice and ratifying the instrument, aiming to promote the construction of knowledge quickly, effectively and also to provide the workshop participant with training to become a multiplier agent of acquired knowledge, according to what Tripp (2005: p. 445) points out: "educational action research is mainly a strategy for the development of teachers and researchers so that they can use their research to improve their teaching and, as a result, the learning of their students".

Table 1. Questionnaire with the questions that was applied to the workshop participants at the end of the activities.

\begin{tabular}{|c|c|c|c|c|c|}
\hline \multirow{2}{*}{ Items evaluated } & \multicolumn{5}{|c|}{ Note Ranges } \\
\hline & $0-2.0$ & $2.1-4.0$ & $4.1-6.0$ & $6.1-8.0$ & $8.1-10.0$ \\
\hline \multicolumn{6}{|l|}{ 1) Teacher didactics } \\
\hline \multicolumn{6}{|l|}{ 2) Accessibility to perform activities } \\
\hline \multicolumn{6}{|l|}{ 3) Own ability to produce Braille printing } \\
\hline \multicolumn{6}{|l|}{ 4) Time available for the lecture } \\
\hline \multicolumn{6}{|l|}{ 5) Time available to make your own prints } \\
\hline \multicolumn{6}{|l|}{ 6) What else would you like to evaluate } \\
\hline Observations & & & & & \\
\hline
\end{tabular}


Still according to Tripp (2005: p. 449): "in order to do action research correctly, we need to be aware of what guides our work, clearly defining what and why we are doing". Based on these precepts, the researcher who taught the workshop was based on his own experiences with handling Braille printers in relation to educational practices, also considering the previous experiences of each workshop participant, seeking in his analyzes a foundation that could be used to readjust the aspects of the pedagogical strategy to be applied.

Figure 1 shows the research path according to the scheme pointed out by Tripp (2005), adapted to show the aspects of the action research carried out in the elaboration and improvement of the workshops carried out.

\subsection{Research Design}

The first workshop class consisted of guests from the Center for Research and Development of Processes, Products and Technological Innovation for the Teaching of Visually Impaired People ("Núcleo de Pesquisa e Desenvolvimento de Processos, Produtos e Inovação Tecnológica para o Ensino de Pessoas com Deficiência Visual"-NDVIS, in Portuguese) registered in the National Council for Scientific and Technological Research ("Conselho Nacional de Pesquisa Científica e Tecnológica”- $\mathrm{CNPq}$, in Portuguese), professionals working at IBC and some people from the inclusion area who work in the state of Rio de Janeiro, in the metropolitan region.

As the demand exceeded the limit of vacancies offered $(n=20)$, it was necessary to select the participants, considering the urgent need to use the printers in question.

In the first workshop, the choice of 27 participants was agreed upon among those who were selected after registration, via NDVIS email $(n=20)$, also involving seven professionals appointed by the IBC management who, despite working with computerized Braille printers, did not have any certification for this.

The individuals selected for the second and third workshops were chosen due to their proximity to the theme: professionals in the area of inclusive specialized education.

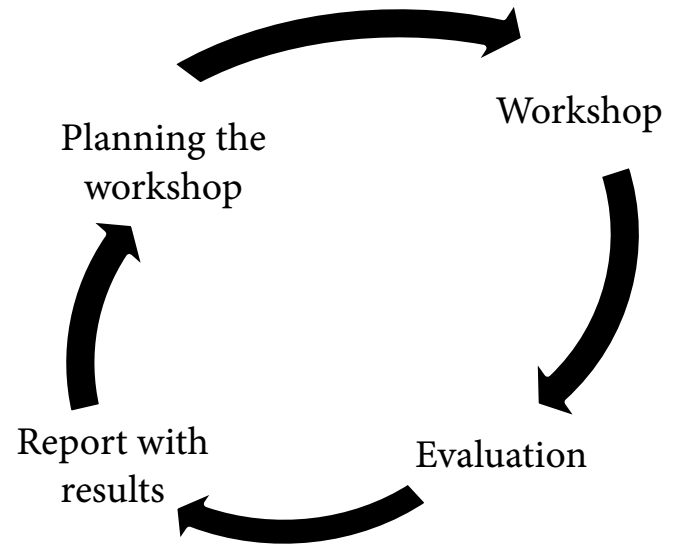

Figure 1. Research-action scheme. 
As the range of professionals who were interested in the invitation was greater than the number of vacancies offered, some criteria of preference for the registration in the workshops were respected: 1) the need for immediate use of Braille printers in professional practice (weight 3 ); 2) the need to master the techniques of Braille printers for research purposes (weight 2);3) curiosity to know the method (weight 1).

The second and third workshops were attended by approximately 20 participants each, a number defined by the availability of courses in the computer lab of the Human Resources Department of the IBC. The responsibility for enrolling students, selecting and distributing the material was, from then on, the responsibility of the IBC's Human Resources Department.

\subsection{Pedagogical Development}

The organization of the "Workshop on Introduction to Configuration and Support for Braille Printing" was carried out in order to offer a quick training for professionals whose time available for learning is reduced, since this situation comprises most cases.

Then, syllabus contents were elaborated to be presented in a period of four hours, divided in explanation through projections of contents and activities of configuration of the printers and printing of material in paper, following the steps of elaboration of a lesson plan divided in: 1) slide presentation; 2) demonstration of the operation of the printers; 3) use and configuration of text and relief printing software and printing activity with students.

The workshop's menu was composed of contents that aimed to provide basic notions of the following topics: 1) Braille printing; 2) Program used for printing; 3) Correct installation of printers on the Windows ${ }^{\circledR}$ System; 4) Configuration and operation of the printers; 5) Basic information on assembly and maintenance.

In the realization of the first workshop, the theoretical contents were designed for the participants and the demonstration of the printers was carried out after dividing the class into two groups of participants. In this step, the connection of the printer, the handling of the control panel, the placement of paper and, finally, Braille printing were demonstrated.

The evaluation of the workshop participants was obtained by printing a sheet with text in Braille and a sheet with relief design. The objectives of evaluating these actions were: to quantify the capacity in handling, printing and checking the material. Assessments could be made individually or in groups.

After each of the three workshops, a questionnaire was applied to the participants to assess the teacher's performance and the teaching strategy adopted (Table 1).

The workshop certification was awarded to students who performed the activities and obtained a satisfactory concept. 


\section{Results}

The three workshops had a total of 47 participants (1st workshop $n=26$; 2nd workshop $n=12$; 3 rd workshop $n=9$ ). In the first one there was the participation of a woman with low vision.

The other two workshops were attended by a blind man in each one. In this way, each workshop had a visually impaired participant.

The insertion of people with disabilities in this type of activity is essential, as the design and functionality of the printers are developed so that these people also have access and can independently configure and use them in a trivial way. It was observed that all participants with visual impairment were included in the groups and had the same performance as the others.

The evaluation of the course by the students was applied at the end of the activities and was characterized by questions about the workshop in which the participant assigned values for some pre-established parameters, with a space for suggestions on more topics being intended with the objective that the active participants of the course process could give their opinion and suggest.

With the results obtained by the application of the first workshop, it was noticed that the first questionnaire, despite being a useful assessment tool, was incomplete and did not include all the complexity of the content presented.

Figure 2 shows the results of the evaluation of the first workshop carried out by the participants. In the applied questionnaire, a space was reserved (Table 1) for the participants to make suggestions about aspects of the workshop.

Only one student made a note, however of total relevance: "the use of printers in other operating systems, in the case mentioned was Linux"”. This free system is used in many schools and educational spaces.

As the printer programs and drivers were not tested in this environment in a timely manner, it was not possible to add it in the first workshop.

The second workshop was reformulated based on the experiences with the participants of the first and from their responses (Figure 3). In this way, the content of the second workshop was more extensive.

Regarding the space used, the second workshop offered an experience more consistent with the proposed activity, as it was held in the recently renovated computer lab. This space has 20 microcomputers for the participants and one for teachers of courses and workshops. In addition, there was a projector and surround sound system for multimedia presentations.

In the second workshop, the evaluation applied in the first was maintained. However, it was necessary to set up a profile of the participants, as they started to be chosen according to the criteria of DCRH which is responsible for all registrations of all courses offered at IBC.

The doubling of the workload of the second and third workshops ( 8 hours) allowed the teacher to focus on practices that reproduced situations that the students had not previously experienced or that were suggested by them. This strategy was intended to put them in a real activity of their day-to-day lives so that they, 
too, can act as multipliers when returning to their home institutions. Figure 3 illustrates the results of the evaluations carried out by those who participated in the second workshop, indicating that it met what had been initially proposed by the teacher.

The third workshop was held with disclosure, registration and realization done within the IBC facilities and, once again, it was offered in the computer lab of Human Resources Training Division a space that proved to be suitable for that and other workshops with similar themes. Again, the blind participant had success equivalent to that of the visionary participants (Figure 4).

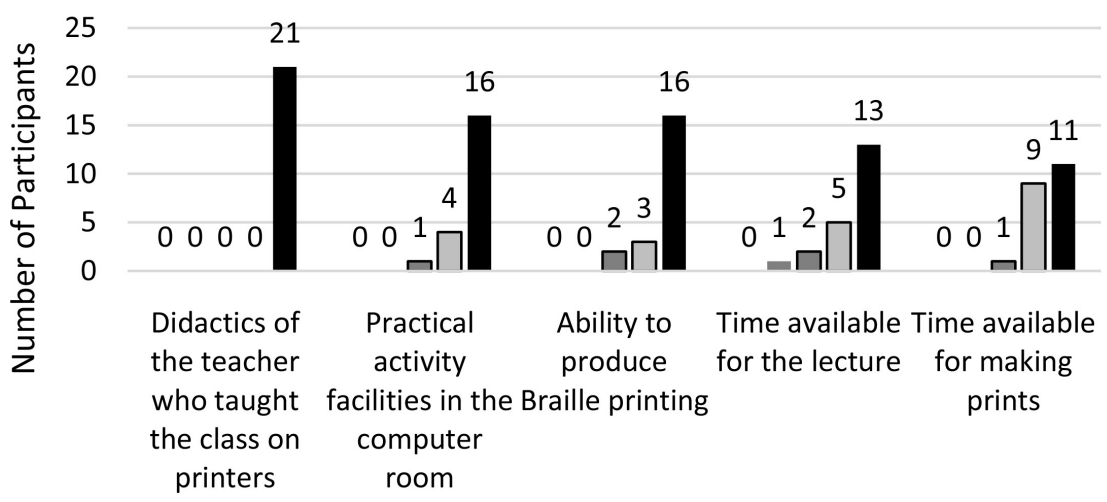

Workshop elements evaluated

$$
0-2.0 \square 2.1-4.0 \quad \square 4.1-6.0 \quad \square 6.1-8.0 \quad \square 8.1-10.0
$$

Figure 2. Results of the evaluation of the first workshop by the participants according to the criteria in Table 1.

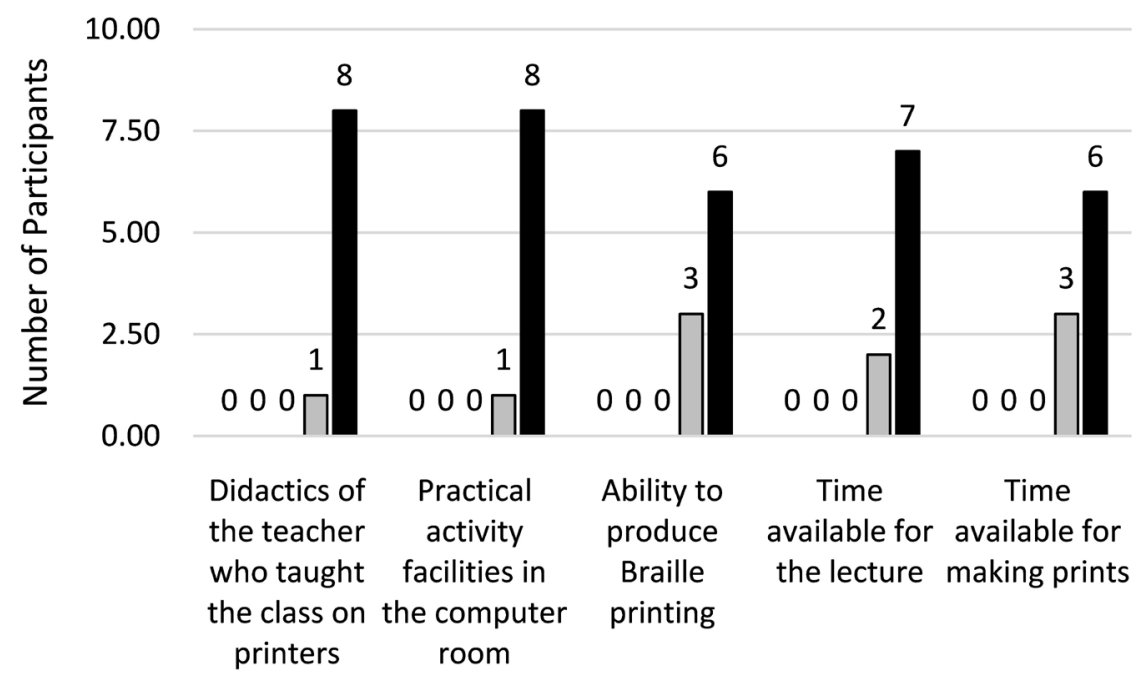

Workshop elements evaluated

$$
0-2.0 \square 2.1-4.0 \square 4.1-6.0 \quad \square 6.1-8.0 \square 8.1-10.0
$$

Figure 3. Results of the evaluation of the second workshop by the participants according to the criteria in Table 1. 


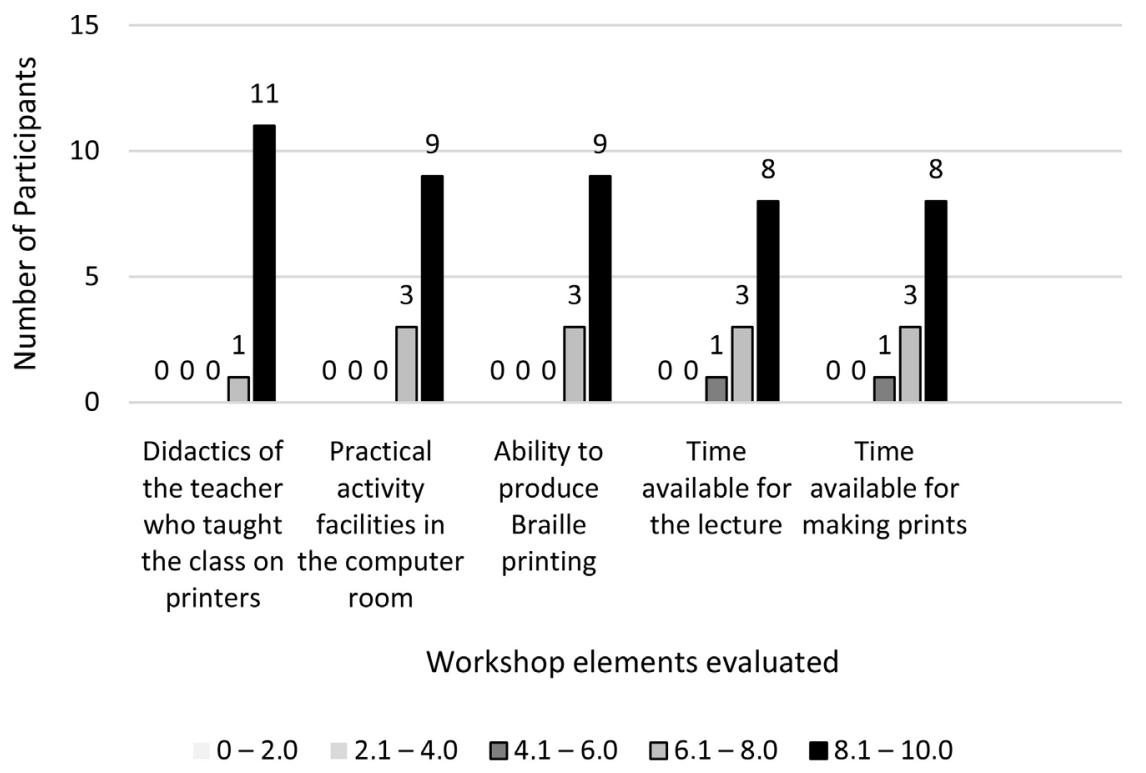

Figure 4. Results of the evaluation of the third workshop by the participants according to the criteria in Table 1.

The lesson plan for the third workshop included questions brought up by participants from the two previous workshops and observed by the teacher, always aiming at improving teaching practice and meeting the proposed objectives.

In this workshop the teacher can propose to the participants the realization of practical activities in which they brought to print graphics and texts, both separately and simultaneously. The reason for this proposal to the participants was the fact that the Easy Braille (Braille Fácil, in Portuguese) program was updated to version 4.0-until then it was not possible to print the graphics together with the text on the Basic-D v4 printers.

The results of the evaluation of the third workshop are illustrated in Figure 4 and show that the quality of the workshop maintained a good average regarding the items considered in the questionnaire, despite being relatively inferior to the results obtained with the application of the second workshop, but still within a spectrum very positive, showing effectiveness in applied strategies and practices.

Based on the premise mentioned above, the teacher experienced and climbed all his practice in explaining the contents, based on the feedback provided by the entities he related to (the participants). It is essential to mention the heterogeneity of their area of activity, a fact that helped the teacher to perceive the disparity between the different education networks at different levels of education (Figure 5).

Most professionals are active in elementary education, while another large portion works in more than one area, such as elementary, secondary and higher education. The other participants are those who attend only secondary, higher education and other areas such as institutions providing rehabilitation services to people with visual impairments, for example. It is important to mention that most of the materials available in Braille such as files for printing in Braille Easy and for download on the internet are not intended for this audience. 


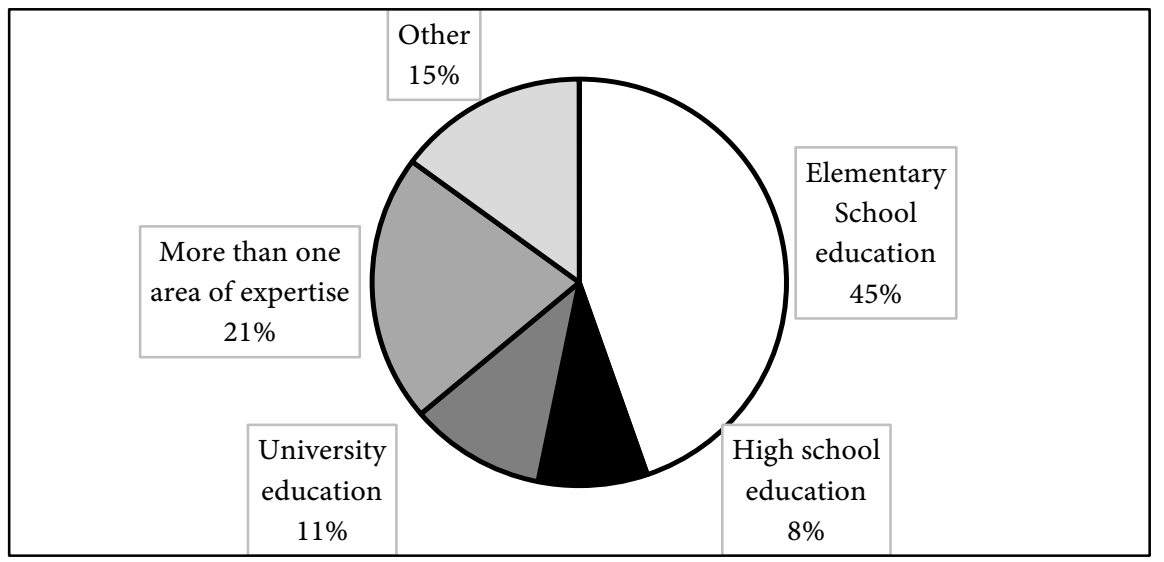

Figure 5. Professional performance area of the 47 participants of the three workshops.

It should be noted that even for those who work in elementary school, the most common practice is to meet the internal demand of the school, that is, materials prepared by the teachers themselves or by the institution where they work, such as through playful activities complemented with Braille texts (Pinho \& Lima, 2016c, Pinho \& Lima, 2017b). Through the experiences of offering the three workshops, it was found that most of the participants were looking for improvement to "do" what they previously did. It is notorious among the participants that several of them developed their own techniques for handling the printers, these being the biggest contributors during the practical activities of the workshop.

The professor also realized that there were those who never had contact with the printers or even knew how to print, but who depended on others to configure the equipment when necessary. In these cases, the theoretical part was emphasized during the workshops, providing a consultation tool with the basic settings of the printers so that the participants could, whenever necessary, return to a standard configuration where printing is possible.

The best way for all participants to be contemplated in their full involvement in the activities and full access to the contents taught has always been investigated, regardless of any extraordinary condition.

Visually impaired participants received all content in an accessible digital format, to be read on screen readers. Their participation in practical activities was crucial, as they acted as evaluators of the impressions of others.

Finally, the participants highlighted the desire that the third workshop along the lines described in the document would become a complete course, together with Easy Braille and Monet, combining its content with the transcription of texts and drawings. Some participants $(n=4)$ indicate a greater need for time for autonomous operation of the printers and the inclusion of other printer models in the workshop's activities.

The results obtained by this study led to the creation of the Workshop on Introduction to Configuration and Support for Braille Printing (Oficina de Introdução à Configuração e Suporte à Impressão Braille, in Portuguese) that comes regularly offered at the Benjamin Constant Institute by Professor Thiago Ribeiro Duarte (http://www.ibc.gov.br/busca?searchword=Thiago\&searchphrase=all). 


\section{Discussion}

The contribution of the participants was fundamental, not only during the workshop itself, but in the preparation of the following workshops (second and third) through their evaluations. According to Cardoso and Burnham, “... the teacher is not only the organizer of the learning process, he is mainly the mediator of the student's' actions" (Cardoso \& Burnham, 2007: p. 77). Such mediation in the teaching-learning process should take place in different educational settings.

In the present study, it was imperative to give each participant an active voice, making them participate in some discussions in which the teacher acted not only as a mediator of the exchange of experience between them, but also with a research subject who can thus report their experience in the present work.

In this practical path, in addition to the acquisition of the concepts presented by the teacher, other questions arose from the participants' own experiences, that is, they assumed a prominent role in their own construction of knowledge, establishing feedback (Figure 1).

The relevance of results obtained through workshop applications that addressed educational themes and the use of technology were reported by Camilo et al. (2016: p. 203),

From the reflections and questions made during the workshop, new possibilities arose to work on reading and writing practices in the classroom, regardless of the level of education in which the teacher works or the student is immersed. Through the practices carried out, it was also possible to demonstrate to participants and future teachers that technology is a facilitating tool for student involvement and motivation with classroom activities (Camilo et al., 2016: p. 293).

As in the research cited, during the workshops held, the presentation of Braille printing technology raised discussions about the range of possibilities in the production of printed materials for blind students who have never had contact with quality materials, since the educational space does not produces correctly or simply does not. It was demonstrated in the workshops, through the printing exercises, that it is possible with the use of the Braille printer to produce teaching materials for use in the classroom and/or resource room, with speed and quality, an objective sought by the participants in general, meeting the requirements of the law (Brazil, 2007; Duarte, 2017).

The practical activities proposed, even those that were adapted for participants with disabilities, were designed and applied with the intention that they create a connection between their experiences, referencing them with those of others, aiming at this with the intense exchange of reports so that it was possible to reproduce in the activities the greatest number of real situations, just like Camilo et al. (2016: p. 288), "the proposed activities aimed at constant interaction between students and an open discussion of points of view."

The participants improve their learning, as they place themselves as actors in a dynamic in which their "doing" is exposed for appreciation and discussion with others during the workshops.

As pointed out by Camilo et al. (2016: p. 283) it is important that there is an 
interaction between prior knowledge of reading and writing.

These authors translated an excerpt from the work of Bernard Schneuwly, from the work "La construcción social del lenguaje written en el niño" (The social construction of written language in children), published in 2008, whose content implies that "writing is no longer just a means to represent something (objects, events and feelings), it is also an instrument to act on reality, an instrument of reflection, an object of play".

Therefore, all writing and reading reflects the subject's culture, his reality and can transform these characteristics through his interaction with the other, whether this is his teacher, his family and friends or even his peers in the classroom.

Firstly, oral language represents first-rate symbolism, as it is when a child transforms signs into objects and relationships that are considered real (Vygotski, 1995).

Secondarily, writing transforms these signs into new meanings, because by differentiating the act of writing from oral speech, the person assimilates the complexity of that which goes far beyond a simple of coordinated motor acts or the domain of the meanings of the dotted lines that form the alphabet in Braille (Vygotski, 1995).

Thus, the psychic and social role of Braille teaching for visually impaired students is indisputable, as reading and writing involve a complex symbolic mental system that favors brain neoformations necessary for the psychic reflexes that enable the most varied human activities (Mello, 2010).

According to Vygotski (1996), the character of writing involves complex processes of abstraction. Thus, debrailization is a setback, as it prevents the creation of literacy conditions for people with visual impairments, limiting the formation of their psychic functions and social and political actions through literacy and literacy.

Still, according to Batista et al. (2018: p. 19):

"from the point of view of the historical-cultural perspective, therefore, written language requires deliberate teaching, arbitrariness and complex levels of abstraction. In addition, it is necessary to create reasons for writing, that is, the social function of writing and its meanings must be present from the beginning of the process of learning to write. Thus, it is from the appropriation of writing that the child starts to become aware of his actions and apply them in different situations of realization of problems that involve ideas, reflections and planning." (Batista et al., 2018: p. 19).

However, what has been verified is that the "educational policies and the pedagogical work in the school contribute to emptying the importance of the teaching of Braille in the production and understanding of the written modality of the language, that is, they intensify the debrailization" (Batista et al., 2018: p. 69).

In this sense, the workshops carried out, went beyond a technical strategy to subsidize the creation of a course to be offered regularly, which generated criticism when making the teacher as to the possibility of providing the participants with autonomy regarding the handling and maintenance of the printers used as well as in the adequate production of materials in Braille, instructions that can 
be replicated in the institutions that are responsible for the production of materials that are so necessary for teaching and updating people with visual impairments.

As reported by Paim et al. (2016: p. 173) in the analysis of a workshop using the evaluation method:

"The construction of a participatory assessment, of a formative character, was carried out through an interactive process and led by those involved in the context, based on continuous dialogue. Thus, an allegedly neutral observer, distant from the object, and whose goal is to reveal the 'truth', does not fit this view. Mediation was essential during the negotiation between the participants, as it was intended to reach consensus, even if it consumed more time and resources, since the evaluation must be a continuous process, which is never completed." (Paim et al., 2016: p. 173).

The similarity between the aforementioned research shows how important it is to use the construction of evaluation, of a formative nature, with the participation of all those involved through the mediation of promoters of knowledge construction (Camilo et al., 2016; Paim et al., 2016).

The choice of materials, the class time, the choice of equipment, the adapted resources, among other elements, were offered and evaluated, constantly, in order to always emphasize the participants' protagonist in their elaboration and, therefore, in its validation as an effective training tool.

The contents were approached in a dynamic and participatory way, giving the participants the opportunity to ask as many questions as possible, making learning meaningful, enabling them to act as multipliers of knowledge in their original units.

This first cycle of three workshops in the research, added to those previously concluded by the Human Resources Department, constituted only the threshold of possibilities in the area of professional training, since the demand is still high despite the demand for the courses still being low due to the impossibility of people to other urban centers travel to the IBC to take the courses.

The final product of the research was presented to the Distance Education Coordination ("Coordenação de Educação à Distância"- $\mathrm{CEaD}$, in Portuguese) and immediately the implementation of this platform format began, which was developed in partnership with the Paulista State University ("Universidade Estadual Paulista Júlio de Mesquita Filho", UNESP_in Portuguese)—the Moodle platform, accessible to people with visual impairments. The Virtual Learning Environment (http://ambientevirtual.nce.ufrj.br) is hosted on the IBC's Distance Learning Coordination website.

Thus, the present study and the elaborated course aimed to contribute in reducing the verifiable lack of training of teachers in regular classrooms and also a lack of collaborative work between them and teachers in Specialized Educational Service ("Atendimento Educacional Especializado", AEE-in Portuguese) to meet the specificities necessary to promote effective teaching of visually impaired people (Vilaronga \& Caiado, 2013; Batista et al., 2017; Batista et al., 2018). The methodology developed by the present study served to elaborate a course that contributes to reduce the critical process of Braille disuse (debrailization). 


\section{Conclusion}

The results obtained by the present study revealed that the didactics of the teacher and the content involved in the elaboration and offer of the workshops were fully approved by the participants. However, part of the participants of the first workshop indicated through the questionnaire that the time for the realization of the lecture and impression should be expanded. Therefore, the workshop time was extended from four to eight hours in duration.

Based on this research and the foundations acquired through the experiences of the teacher and workshop participants, it was possible to create a mechanism for continuous training through the provision of continuing training courses at IBC, where the target audience may, at the end, act as a multiplier in the networks to which they belong and, in addition, form a collaboration network between Braille production centers, universities and graduate programs that develop research on this theme so that all printers distributed by the Brazilian's Ministry of Education or those acquired by schools can always be available to teachers to provide quality printed material for students with visual impairments to have access to writing and embossed images, which are essential for schooling and academic training through the Braille System. The course offered at IBC follows the steps of preparing the lesson plan used for eight hours.

The continuous training of professionals who work in specialized educational assistance to students with visual impairments through the production and use of texts in Braille is essential to guarantee this segment the essential access to autonomous knowledge.

The results of the present study also contribute to the discussion on the phenomenon of debrailization. It is hoped that this phenomenon will not reach the next generations of visually impaired students who have been developing their schooling in regular classes from the perspective of Inclusive Education.

It should be noted that the development of new technologies has inadequately replaced the teaching and learning practices through Braille, as such technological advances have not yet become literate.

In parallel, there are still many difficulties in implementing public policies aimed at inclusion. Therefore, all actions that reduce the growing process of de-liberalization combined with the political changes of special education, especially in relation to the resource room and common room, contribute to the effective literacy and literacy processes of people with visual impairments.

These actions enable psychic development, their full autonomy and their greater political and social participation.

Finally, the importance of exchanging ministerial bodies, universities and teaching departments in the organization of collaborative networks for the training of professionals capable of using Braille Basic-D v4 and Enabling Juliet pro 60 printers should be considered, in order to contribute to knowledge theoretical and practical skills necessary for the technical production of books and other materials in Braille for students with visual impairments. 


\section{Acknowledgements}

We thank UFF, UERJ, CAPES, CNPq, and FAPERJ for fellowships and financial support.

\section{Conflicts of Interest}

The authors declare no conflicts of interest regarding the publication of this paper.

\section{References}

Almeida, M. G. S. (2014). The Importance of Literature as an Element in the Construction of the Imagination of Children with Visual Impairment. Instituto Benjamin Constant. http://www.ibc.gov.br/images/conteudo/livros/miolos_livros/A-IMPORTANCIA-DALITERATURA.pdf

Associação de Pais e Amigos dos Deficientes Visuais (2020). The Braille System in Brazil. http://apadev.org.br/pages/workshop/Osistemabrailenobrasil.pdf

Batista, R. D. (2017). The Process of Literacy of Blind Students and the Movement towards Debrailization. Universidade Metodista de Piracicaba.

Batista, R. D., Amaral, M. H., \& Monteiro, M. I. B. (2018). Who Teaches Braille to Blind Students? Teacher Training in Question. Horizontes, 36, 36-49.

https://revistahorizontes.usf.edu.br/horizontes/article/view/676/327 https://doi.org/10.24933/horizontes.v36i2.676

Batista, R. D., Lopes, E. R., \& Pinto, G. U. (2017). The Literacy of Blind Students and the Trends of Debrailization: A Necessary Discussion. Revista de Ciências da Educação, 19, 179-194. https://www.revista.unisal.br/ojs/index.php/educacao/article/view/587/403

Belarmino, J. (2001). The New Technologies and the "Debrailization": Myth or Reality. I Seminário Nacional de Bibliotecas Braille. João Pessoa, Brazil. http://intervox.nce.ufrj.br/ joana/textos/tecni08.html

Bigate, T. F., \& Lima, N. R. W. (2019). Pedagogical Practices in the Rehabilitation Process of Students with Deaf Blindness. Revista Educação Especial, 32, 66.

https://periodicos.ufsm.br/educacaoespecial/article/view/34756/34756 https://doi.org/10.5902/1984686X34756

Bigate, T. F., Lima, N. R. W., Ferreira, R. M. R., \& Mariani, R. M. (2017). Museum of Tomorrow: Accessibility Resources for the Visually Impaired. Revista Aleph, 29, 354-379. https://periodicos.uff.br/revistaleph/article/view/39237/22673

Borges, J. A. S. (2009). From Braille to DOSVOX-Differences in the Lives of Brazilian Blind People. Rio de Janeiro: Universidade Federal do Rio de Janeiro. http://intervox.nce.ufrj.br/dosvox/textos/tese_antonio_borges.pdf

Borges, J. A. S., \& Chagas Jr., G. J. F. (2001). Braille Printing in Brazil: The Role of Braivox, Easy Braille and Painter Braille. Banco de Escola: Educação para todos. http://www.bancodeescola.com/borges.htm

Brazil. Law No. 9,394, of December 20 (1996). Establishes the Guidelines and Bases of National Education. Law of Guidelines and Bases of Education-LDB. Brasília. http://www.planalto.gov.br/ccivil_03/leis/L9394.htm

Brazil. Normative Ordinance No. 13, of April 24 (2007). Provides for the Creation of the Program for the Implementation of Multifunctional Resource Rooms. Brasília. https://www.jusbrasil.com.br/diarios/6747587/pg-59-secao-03-diario-oficial-do-distrito -federal-dodf-de-26-04-2007 
Camilo, A. R. T., Becker, S., \& Fontanella, V. A. (2016). Reading and Writing Workshop Inspired by Literature, Cinema and Fantasy. Revista Digital do Programa de Pós-Graduação em Letras, 9, 282-294. http://file:///D:/Downloads/23551-107283-1-PB.pdf

Cardoso, A. L. M. S., \& Burnham T. F. (2007). Collaborative Construction of Knowledge with Learning Objects in a Virtual Learning Environment. Informática na Educação: Teoria e Prática, 10, 1-12.

https://seer.ufrgs.br/InfEducTeoriaPratica/article/view/2485/2897 https://doi.org/10.22456/1982-1654.2485

Duarte, T. R. (2017). Configuration and Support for BRAILLE Printing: Training for the Production of Teaching Material for the Visually Impaired. Master Dissertation (Mestrado em Diversidade e inclusão, Universidade Federal Fluminense).

http://cmpdi.sites.uff.br/wp-content/uploads/sites/186/2018/08/Dissertação-ThiagoRib eiroDuarte.pdf

Duarte, T. R., \& Lima, N. R. W. (2017). Adaptation of Textbooks to the Braille System: An Inclusive Proposal. In N. R. W. Lima, \& C. M. C. Delou (Org.), Pontos de Vista em Diversidade e Inclusão (Vol. 2, pp. 147-150). Niterói: ABDIn/PERSE.

http://divulgacaocientificacmpdi.sites.uff.br/wp-content/uploads/sites/330/2019/01/EB ook-vol-2-Pontos-de-Vista-em-Diversidade-e-Inclus\%C3\%A3o.pdf

Franco, J. R., \& Dias, T. R. S. (2007). The Education of Blind People in Brazil. Avesso do Avesso, 5, 74-82.

http://www.feata.edu.br/downloads/revistas/avessodoavesso/v5_artigo05_educacao.pdf

Lemos, E. R., \& Cerqueira, J. B. (1996). The Braille System in Brazil. Revista Benjamin Constant, No. 2, 13-17. http://www.ibc.gov.br/revistas/197-edicao-02-janeiro-de-1996

Lima, N. R. W. (2015). Talking about the Evolution of Sex-Audiobook. Rio de Janeiro: IBC.

Lima, N. R. W., \& Fonseca, J. P. (2014). Telling the Story of the Giant Panda-Audiobook. Niterói: FDNC/EDUFF.

Loomis, M. S. (1942). The Braille Reference Book. New York: Harper \& Brothers.

Mello, S. A. (2010). Teach and Learn Written Language from a Historical and Cultural Perspective. Psicologia Política, 10, 329-343.

Moraes, M. E. L. (2016). Tactile Reading and the Effects of Debrailization in Mathematics Classes. Mestrado do Programa de Pós-Graduação em Educação em Ciências e Matemática, Universidade Federal do Pará.

National Braille Week (2020). Who Was Louis Braille? https://www.royalblind.org/national-braille-week/about-braille/who-was-louis-braille

Noah, K. (2013). Who Invented Braille? http://www.todayifoundout.com/index.php/2013/11/history-braille/

Nunes, S. L., \& Bitencourt, J. F. (2010). The Blind Student: Prejudices and Potential. Revista semestral da Associação Brasileira de Psicologia Escolar e Educacional, 14, 55-64. http://www.scielo.br/pdf/pee/v14n1/v14n1a06 https://doi.org/10.1590/S1413-85572010000100006

Orrico, H., Canejo, E., \& Fogli, B. (2009). A Reflection on the School Routine of Visually Impaired Students in Regular Classes. In R. Glat (Org.), Inclusive Education: Culture and School Life (Vol. 1, pp. 116-136). Rio de Janeiro: Letters.

Paim, M. B., Kovaleski, D. F., \& Moretti-Pires, R. O. (2016). Participatory Evaluation: Analysis of the First VER-SUS Florianópolis (SC) Workshop. Revista Saúde em Debate, 40, 169-178. http://cebes.org.br/site/wp-content/uploads/2017/01/RSD111-web.pdf https://doi.org/10.1590/0103-1104201611113 
Perdigão, L. T., \& Lima, N. R. W. (2017). Seeing with Different Eyes: Audio Description in Higher Education at a Distance. NITERÓI: ABDIn/PERSE. http://educapes.capes.gov.br/handle/capes/429946

Pinho, T. M. M., \& Lima, N. R. W. (2016c). Teaching Mathematics in the Dark. In N. R. W. Lima, \& C. M. C. Delou (Org.), Pontos de Vista em Diversidade (pp. 69-84). Niterói: ABDIn/PERSE.

http://www.perse.com.br/novoprojetoperse/BSU_Data/Books/N1461693489167/Amost ra.pdf

Pinho, T. M. M., \& Lima, N. R. W. (2017a). Folding and Collages in the Teaching of Geometry for Blind Elementary School Students during the Counter-Shift Period. Ensino e Pesquisa, 15, 237-253.

http://periodicos.unespar.edu.br/index.php/ensinoepesquisa/article/view/13/pdf_47

Pinho, T. M. M., \& Lima, N. R. W. (2017b). The Use of Music in a Geometry Workshop for Blind Elementary School Students. In N. R. W. Lima, L. T. Perdigão, \& C. M. C. Delou (Org.), Pontos de Vista em Diversidade e Inclusão (Vol. 3, pp. 146-154). Niterói: ABDIn/PERSE.

http://divulgacaocientificacmpdi.sites.uff.br/wp-content/uploads/sites/330/2019/01/EB ook-vol-3-Ponto-de-vista-em-Diversidade-e-Inclus\%C3\%A3o.pdf

Pinho, T. M. M., Castro, H. C., Alves, L., \& Lima, N. R. W. (2016a). Mathematics and Blindness: Let's Try to Solve This Problem? Schooled International Journal of Multidisciplinary \& Allied Studies, 3, 215-225.

https://www.researchgate.net/publication/310898208_Mathematics_and_blindness_let' s_try_to_solve_this_problem https://doi.org/10.19085/journal.sijmas031002

Pinho, T. M. M., Delou, C. M. C., \& Lima, N. R. W. (2016b). Origami as a Tool to Teach Geometry for Blind Student. Creative Education, 7, 2652-2665.

https://www.scirp.org/pdf/CE_2016111610581230.pdf https://doi.org/10.4236/ce.2016.717249

Silva, L. F. (2001). Braille Textbook: Some Questions. Revista Benjamin Constant, No. 19, 32 .

Souza, D. B., Batista, C. P., \& Matos, M. A. (2016). The Braille System and Information Technology, Moving Together to Include. Natal, Brazil: III Congresso Nacional de Educação.

https://www.editorarealize.com.br/revistas/conedu/trabalhos/TRABALHO_EV056_M D1_SA7_ID8401_13082016231555.pdf

Souza, J. B. (2001). The New Technologies and the "Debrailization": Myth or Reality. Anais do Seminário Nacional de Bibliotecas Braille. João Pessoa. http://intervox.nce.ufrj.br/ joana/textos/tecni08.html

Souza, J. B. (2018). Blindness, Accessibility and Inclusion: Notes of a Trajectory. Psicologia: Ciência e Profissão, 38, 564-571. https://doi.org/10.1590/1982-3703000092018

Tederixe, L. C. (2019). Tactile Book: Teaching and Learning Possibilities for the Blind Child. Mestrado em Diversidade e inclusão, Universidade Federal Fluminense.

Tripp, D. (2005). Action Research: A Methodological Introduction. Educação e Pesquisa, 31, 443-466. https://doi.org/10.1590/S1517-97022005000300009

Vilaronga, C. A. R., \& Caiado, K. R. M. (2013). Schooling Processes for Visually Impaired People. Revista Brasileira de Educação Especial, 19, 61-78.

http://www.scielo.br/pdf/rbee/v19n1/05.pdf

https://doi.org/10.1590/S1413-65382013000100005 
T. R. Duarte et al.

Vygotski, L. S. (1995). The Pre-History of Written Language Development. In Selected Works (Vol. 3). Madrid: Visor.

Vygotski, L. S. (1996). Thought and Language. São Paulo: Martins Fontes. 